\title{
Effects of light and temperature on isoprene emission at different leaf developmental stages of Eschweilera coriacea in central Amazon
}

\author{
Eliane Gomes ALVES ${ }^{*}$, Peter HARLEY², José Francisco de C. GONÇALVES ${ }^{3}$, Carlos Eduardo da Silva \\ MOURA $^{4}$, Kolby JARDINE 5 \\ Climate and Environment Department, National Institute for Amazon Research (INPA), Graduate Program in Climate and Environment, University of Amazon State. Manaus, \\ Amazonas, Brazil. \\ *Corresponding Author: elianegomes.alves@gmail.com \\ 2 Atmospheric Chemistry Division, National Institute for Atmospheric Research (NCAR). Boulder, U.S.A. harley@ucaredu \\ ${ }^{3}$ Laboratory of Plant Physiology and Biochemistry, National Institute for Amazon Research (INPA). Manaus, Amazonas, Brazil. jfc@inpa.gov.br \\ ${ }^{4}$ Laboratory of Plant Physiology and Biochemistry, National Institute for Amazon Research (INPA). Manaus, Amazonas, Brazil. carlosmoura.dr@gmail.com \\ ${ }^{5}$ Climate Science Department, Earth Science Division, Lawrence Berkeley National Laboratory. Berkeley, U.S.A. kjjardine@lbl.gov
}

\begin{abstract}
Isoprene emission from plants accounts for about one third of annual global volatile organic compound emissions. The largest source of isoprene for the global atmosphere is the Amazon Basin. This study aimed to identify and quantify the isoprene emission and photosynthesis at different levels of light intensity and leaf temperature, in three phenological phases (young mature leaf, old mature leaf and senescent leaf) of Eschweilera coriacea (Matamatá verdadeira), the species with the widest distribution in the central Amazon. In situ photosynthesis and isoprene emission measurements showed that young mature leaf had the highest rates at all light intensities and leaf temperatures. Additionally, it was observed that isoprene emission capacity $(E)$ changed considerably over different leaf ages. This suggests that aging leads to a reduction of both leaf photosynthetic activity and isoprene production and emission. The algorithm of Guenther et al. (1999) provided good fits to the data when incident light was varied, however differences among $E_{S}$ of all leaf ages influenced on quantic yield predicted by model. When leaf temperature was varied, algorithm prediction was not satisfactory for temperature higher than $-40^{\circ} \mathrm{C}$; this could be because our data did not show isoprene temperature optimum up to $45^{\circ} \mathrm{C}$. Our results are consistent with the hypothesis of the isoprene functional role in protecting plants from high temperatures and highlight the need to include leaf phenology effects in isoprene emission models.
\end{abstract}

KEYWORDS: light response curve, temperature response curve, leaf phenology, tropical species.

\section{Efeitos da luz e da temperatura sobre a emissão de isopreno em diferentes estádios de desenvolvimento foliar de Eschweilera coriacea na Amazônia Central}

\begin{abstract}
RESUMO
O isopreno emitido pelas plantas corresponde em cerca de um terço das emissóes globais de compostos orgânicos voláteis anualmente. A maior fonte de emissão de isopreno para a atmosfera global é a Bacia Amazônica. Este estudo objetivou identificar e quantificar a emissão de isopreno e fotossíntese em diferentes níveis de intensidade de luz e temperatura foliar, em três fases fenológicas (folha madura recente, folha madura tardia e folha senescente) de Eschweilera coriacea (Matamatá verdadeira) a espécie com maior distribuição na Amazônia central. In situ, as medidas de fotossíntese e emissão de isopreno da folha madura recente apresentaram as maiores taxas em todos os níveis de luz e de temperatura. Adicionalmente, a capacidade de emissáo de isopreno $\left(E_{S}\right)$ mudou consideravelmente entre as diferentes idades foliares, sugerindo que o envelhecimento reduz a atividade fotossintética e a produção/emissão de isopreno. O algoritmo de Guenther et al. (1999) demonstrou bom ajuste para a emissão de isopreno em diferentes intensidades de luz, entretanto, diferenças na $E_{S}$ entre as idades foliares influenciaram no rendimento quântico estimado pelo modelo. Em relação à temperatura foliar, a estimativa do algoritmo não foi satisfatória para as temperaturas acima de $-40^{\circ} \mathrm{C}$; isto provavelmente ocorreu pelo fato dos dados não apresentarem temperatura ótima até $45^{\circ} \mathrm{C}$. Nossos resultados sáo consistentes com a hipótese do isopreno ter um papel funcional para proteger as plantas de altas temperaturas e apontam a necessidade de incluir os efeitos da fenologia foliar em modelos de emissão de isopreno.
\end{abstract}

PALAVRAS-CHAVE: curva de luz, curva de temperatura, fenologia foliar, espécie tropical. 


\section{INTRODUCTION}

Terrestrial vegetation emits many non-methane Biogenic Volatile Organic Compounds (BVOCs), including hydrocarbons (isoprene, monoterpenes and sesquiterpenes) and oxygenated organic compounds (e.g., methanol and acetone) (Guenther 2002). These compounds have many effects on atmospheric chemistry and climate (Pacifico et al. 2009). Isoprene (2-methyl-1,3-butadiene, $\mathrm{C}_{5} \mathrm{H}_{8}$ ) is quantitatively the most important of the BVOCs, with an estimated global annual emission of about 400-600 TgC (see table 1 of Arneth et al. 2008). Terrestrial plant foliage is a source of $>90 \%$ of atmospheric isoprene and it is generally assumed that tropical forests provide most of the global isoprene budget (Guenther et al. 2006).

The ability to produce isoprene is widespread in the plant kingdom (Harley et al. 2004), and this production has been shown to depend on environmental factors, primarily light and temperature (Guenther et al. 1993; Sharkey and Singsaas 1995; Niinemets et al. 2010). Isoprene is not stored within the plant and although its function remains open to debate, experiments have demonstrated that high levels of isoprene within leaves confer protection against high temperatures (Singsaas et al. 1997; Peñuelas et al. 2005; Velikova and Loreto 2005), and oxidants (Loreto and Velikova, 2001). Studies with plants grown under different incident photosynthetic photon flux densities in constant temperature environments have also demonstrated positive correlations between light availability and isoprene emissions (Litvak et al. 1996; Hanson and Sharkey 2001).

In addition to effects of short-term environmental (light and temperature) fluctuations, leaf developmental variations also influence on isoprene production. Isoprene synthase activity, absent in very young leaves, increases gradually until full leaf maturation and decreases thereafter with the onset of leaf senescence (Schnitzler et al. 1997). The physiological activity of foliage varies in dependence on leaf ontogenetic stage, increasing rapidly in developing leaves and decreasing in senescing leaves undergoing programmed cell death (Niinemets et al. 2004). This decline in leaf physiological activity is also associated with strong reductions in foliage isoprene emission rates (Lehning et al. 2001; Mayrhofer et al. 2005; Sun et al. 2009).

The Amazon forest is the largest area of tropical rainforest and is representative of tropical forests in general, so that models predicting emissions of BVOCs from this critically important global biome provide necessary inputs to models of atmospheric chemistry and biogeochemical cycling at regional and global scales. Therefore, studies of isoprene emission in relation to environmental factors (light and temperature) and leaf developmental variations are important to improve emission models of isoprene and other important trace gas species. This is the first study that clearly shows isoprene emission at leaf level from Eschweilera coriacea (DC.) S. A. Mori, the most abundant tree species in the central Amazon. In addition, we characterized the effects of leaf temperature and light availability on photosynthesis and isoprene emission at different leaf developmental stages of this species.

\section{MATERIALS AND METHODS}

\section{Site description}

The species investigated occurs on a plateau of the Reserva Biológica do Cuieiras, a primary rainforest biological reserve located approximately $100 \mathrm{~km}$ north of Manaus, in the central Amazon Basin, in Amazonas, Brazil ( $2^{\circ} 36.67^{\prime}$ S, 60 $12^{\circ}$ 33.48 ” W, $130 \mathrm{~m}$ a.s.1.). This reserve has an area of about $230 \mathrm{~km}^{2}$ and belongs to the National Institute for Amazon Research (INPA) (Andreae et al. 2002). Soils are well drained Oxisols and Ultisols on the plateau and slopes, respectively, and poorly drained Spodosols in the valleys (Ferraz et al. 1998; Luizão et al. 2004). The diversity of species is above 200 species ha-1 (Oliveira and Amaral 2005). The canopy is dense, resulting in greatly reduced light availability in the forest understory and on the forest floor (Oliveira et al. 2008). Annual rainfall is about $2400 \mathrm{~mm}$ and average air temperature ranges between $26{ }^{\circ} \mathrm{C}$ (in April) and $28^{\circ} \mathrm{C}$ (in September). The wetter period extends from December to April, and the drier period from June to September, when rainfall is less than $100 \mathrm{~mm}$ per month (Araújo et al. 2002).

\section{Isoprene data collection and analysis}

Measurements of isoprene emission and photosynthesis of the canopy tree species Eschweilera coriacea were carried out in the months of October and November 2010, during the dry-to-wet season transition. Measurements were made on single leaves at three different developmental stages in the top layer of the canopy: young mature leaf (recently fully expanded), old mature leaf (longer period since full expansion) and senescent leaf. Although E. coriacea is the most abundant tree species in the central Amazon, photosynthesis and isoprene data collection were obtained in a single plant because of logistic difficult to get to canopy tree in the Amazon Forest. Nevertheless, these data may indicate the pattern of photosynthesis and isoprene emission in a tropical species, since data like these are very scarce.

Photosynthesis measurements were carried out between 8 and $12 \mathrm{~h}$, using a commercial portable photosynthesis system (LI-6400, LI-COR, Inc, Lincoln, NE, USA). The flow rate of air into the leaf chamber was $400 \mu \mathrm{mol} \mathrm{s}{ }^{-1}$, and $\mathrm{CO}_{2}$ and $\mathrm{H}_{2} \mathrm{O}$ concentrations inside the chamber were $380 \pm 4 \mu \mathrm{mol}$ $\mathrm{mol}^{-1}$ and $21 \pm 3 \mathrm{mmol} \mathrm{mol}^{-1}$, respectively. The LI-6400 was set to photosynthetic photon flux density (PPFD) and leaf temperature variations. 
To measure isoprene emissions, air exiting the LI-6400 leaf chamber was routed to fill a 0.5 Tedlar sampling bag with single polypropylene septum fitting (SKC, Inc., Eighty Four, PA, USA); for each sampling one bag was filled to approximately 0.4 liter. In order to avoid chemical conversion of the primary emitted isoprene to oxygenated compounds inside the leaf enclosure and to remove isoprene from the incoming ambient air, activated charcoal filters (ORBO 32, Sigma-Aldrich, St. Louis, MO, USA) were installed at the air inlet of LI-6400 to remove ozone and hydrocarbons. Additionally, before each measurement a chamber blank sample was obtained from the empty leaf chamber. All tubing in contact with the sampling air was Teflon.

Isoprene concentrations (ppbv) in the bag samples were quantified within 3 hours after collection using a commercial high sensitivity proton transfer reaction mass spectrometry (PTR-MS, IONICON, Austria). The PTR-MS was operated in standard conditions and isoprene concentrations were determined as previously described (Jardine et al. 2011).

Once the volume mixing ratio of isoprene (ppbv) was obtained, leaf emission flux was determined using the following equation:

$$
F=R_{p p b v} \times \frac{Q}{A}
$$

where $F\left(\mathrm{nmol} \mathrm{m}{ }^{-2} \mathrm{~s}^{-1}\right)$ is leaf flux of isoprene emission; $R_{p p b v}\left(\mathrm{nmol} \mathrm{mol}{ }^{-1}\right)$ is isoprene concentration of sample; $Q$ is flow rate of air into the leaf chamber $\left(400 \times 10^{-6} \mathrm{~mol} \mathrm{~s}^{-1}\right)$; and $A$ is the area of leaf within the chamber $\left(0.0006 \mathrm{~m}^{2}\right)$. Using this equation, units of isoprene emission were $\mathrm{nmol} \mathrm{m}^{-2} \mathrm{~s}^{-1}$. For conversion to units of mass, specific leaf mass was determined ( $\mathrm{g}$ dry mass $\mathrm{m}^{-2}$ ), where the dry weight was obtained using a microbalance (AY220, Shimadzu, Philippines) after drying leaves in a ventilated oven $\left(65^{\circ} \mathrm{C}\right)$ for $72 \mathrm{~h}$. The mass units of isoprene emission were $\mu \mathrm{g} \mathrm{C} \mathrm{g}{ }^{-1} \mathrm{~h}^{-1}$.

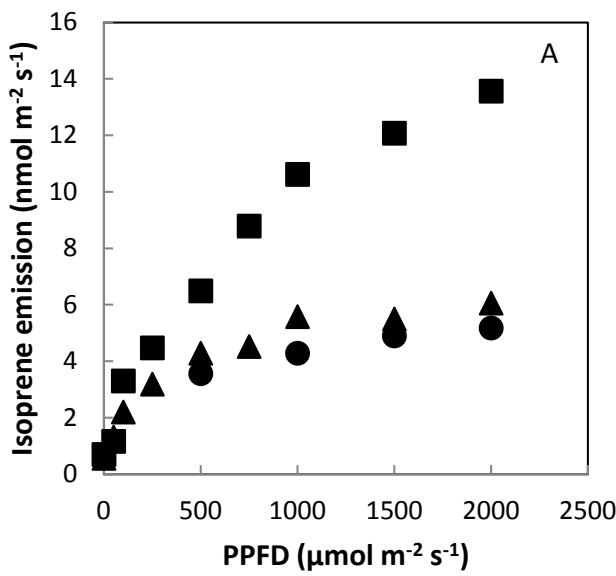

\section{Light and temperature response curves}

Photosynthesis and isoprene emission rates were quantified at different levels of incident light (PPFD) and leaf temperature for three leaf developmental stages (young mature leaf, older mature leaf and senescent leaf). In the light response curves, measurements were made at nine increasing levels of irradiance $(0,50,100,250,500,750,1000,1500$, $\left.2000 \mu \mathrm{mol} \mathrm{m} \mathrm{s}^{-1}\right)$ under constant leaf temperature $\left(30 \pm 1^{\circ} \mathrm{C}\right)$. At each PPFD level, after the establishment of steady-state photosynthesis, a bag sample (approx. $0.4 \mathrm{l}$ ) of air exiting the chamber was collected in around one minute.

For temperature response curves, measurements were made under constant irradiance $\left(1000 \mu \mathrm{mol} \mathrm{m}^{-2} \mathrm{~s}^{-1}\right)$ and leaf temperature was varied between approximately $25^{\circ} \mathrm{C}$ and 45 ${ }^{\circ} \mathrm{C}$. Because the thermoelectric temperature controllers could only regulate cuvette temperature within approximately $8^{\circ} \mathrm{C}$ below and $10^{\circ} \mathrm{C}$ above ambient temperature (e.g. Keller and Lerdau 1999), the actual range of each temperature response curve depended upon the ambient temperature at the time of measurement. At each leaf temperature, one sample was collected around one minute after leaf photosynthetic rate had reached steady state. For leaf temperatures above $30^{\circ} \mathrm{C}$, the collection was made 15 minutes after the establishment of apparent steady-state photosynthesis.

\section{RESULTS}

\section{Isoprene emission capacity $\left(E_{s}\right)$ for different developmental stages}

Isoprene emission capacity $(E)$, which is determined at standard conditions $\left(30{ }^{\circ} \mathrm{C}\right.$ and $1000 \mu \mathrm{mol} \mathrm{m} \mathrm{m}^{-2} \mathrm{~s}^{-1}$ of PPFD), obtained from the light response curve (Figure 1a) showed that $E$ of the young mature leaf was $124 \%$ higher than $E$ of the older mature leaf, and $92 \%$ higher than $E_{s}$ of the senescent leaf (Table 1).

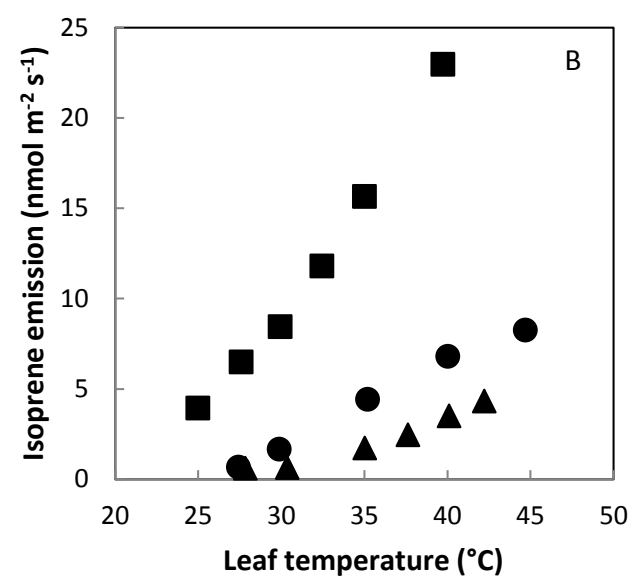

Figure 1 - Response of isoprene emission from different leaf developmental stages of $E$. coriacea to variations in PPFD (A) and leaf temperature (B). Senescent leaf $(\mathbf{\Lambda})$; old mature leaf $(\bullet)$; young mature leaf $(\mathbf{\bullet})$. 
Table 1 - Photosynthesis, isoprene emission capacity and percentage of carbon emitted in form of isoprene at standard conditions $\left(30^{\circ} \mathrm{C}\right.$ and $1000 \mu \mathrm{mol} \mathrm{m}^{-2} \mathrm{~s}^{-1}$ of PAR)

\begin{tabular}{|c|c|c|c|c|c|c|c|}
\hline & $\begin{array}{c}\text { Leaf Development } \\
\text { Stage }\end{array}$ & 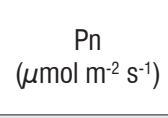 & $\begin{array}{c}\text { Es } \\
\left(\mathrm{nmol} \mathrm{m} \mathrm{m}^{-2} \mathrm{~s}^{-1}\right)\end{array}$ & $\begin{array}{l}\text { Specific } \\
\text { Leaf Mass } \\
\left(\mathrm{g} \mathrm{m}^{-2}\right)\end{array}$ & $\begin{array}{c}P n \\
\left(\mu g \mathrm{C} \mathrm{g}^{-1} \mathrm{~h}^{-1}\right)\end{array}$ & $\begin{array}{c}\text { Es } \\
\left(\mu \mathrm{Cg}^{-1} \mathrm{~h}^{-1}\right)\end{array}$ & $\begin{array}{c}\% \text { of fixed } 0 \\
\text { emitted as } \\
\text { isoprene }\end{array}$ \\
\hline Temperature & YML & 8.41 & 8.45 & 134.87 & 2700 & 13.54 & 0.5 \\
\hline Response & OML & 3.33 & 1.67 & 123.55 & 1170 & 2.92 & 0.25 \\
\hline Curve & SL & 2.79 & 0.65 & 137.7 & 877 & 1.03 & 0.12 \\
\hline Light & YML & 9.96 & 9.6 & 142.41 & 3022 & 14.56 & 0.48 \\
\hline Response & OML & 4.65 & 4.28 & 123.55 & 1628 & 7.49 & 0.46 \\
\hline Curve & SL & 3.86 & 5 & 137.7 & 1211 & 10.07 & 0.83 \\
\hline
\end{tabular}

Note: $P_{N}$ is photosynthetic rate; $E_{S}$ is isoprene emission capacity. $\mathrm{OML}=$ old mature leaf; $\mathrm{SL}=$ senescent leaf; $\mathrm{YML}$ = young mature leaf.

In addition, results showed lower values of photosynthesis and isoprene emission for older leaves in all light levels applied (Figure $2 \mathrm{a}-\mathrm{c}$ ).

$E_{s}$ obtained from the temperature response curves (Figure $1 b)$ also showed that isoprene emission of young mature leaf was higher than $E$ of older mature leaf, and higher than $E$ of senescent leaf (Table 1). Young mature leaf showed the highest values of isoprene emission and photosynthesis in all leaf temperatures (Figure 2 d-f).

\section{Light and temperature responses}

Results showed that all leaf developmental stage responses of isoprene emission to varying light were similar to responses of photosynthesis, which approximates a rectangular hyperbola (Figure $2 \mathrm{a}-\mathrm{c}$ ), highlighting the light dependence of isoprene emission.

Although the light response of isoprene and photosynthesis were similar, the light level at which the two processes saturated differed for all leaf ages. The light saturation of photosynthesis occurred at $1000 \mu \mathrm{mol} \mathrm{m} \mathrm{m}^{-2} \mathrm{~s}^{-1}$ of PPFD which was lower than light saturation of isoprene emission, so that the pattern of light-dependence for isoprene emission fails to show light saturation below $2000 \mu \mathrm{mol} \mathrm{m} \mathrm{m}^{-2} \mathrm{~s}^{-1}$; emissions increased by about $5.5 \%, 9 \%$, and $11 \%$ as light was raised from 1500 to $2000 \mu \mathrm{mol} \mathrm{m} \mathrm{m}^{-2} \mathrm{~s}^{-1}$ for older mature leaf, senescent leaf and young mature leaf, respectively (Figure $2 \mathrm{a}-\mathrm{c}$ ).

The light response of isoprene for all leaf developmental stages was modeled using the light algorithm of Guenther $e t$ al. (1999) corrected by Monson et al. (2012),

$$
\text { emission rate }=\varepsilon_{0} \frac{\alpha \times C_{L_{1}} \times L}{\sqrt{1+\frac{\alpha^{2} \times L^{2}}{C p_{5}^{2}}}}
$$

where $\varepsilon_{0}$ is the emission rate under standard conditions of $30{ }^{\circ} \mathrm{C}$ and PPFD equals to $1000 \mu \mathrm{mol} \mathrm{m} \mathrm{m}^{-2} \mathrm{~s}^{-1}$; and $\alpha$ and $\mathrm{C}_{\mathrm{L} 1}$ are empirical coefficients; and $\mathrm{C}_{\mathrm{p} 5}$ is an additional coefficient for the mathematical correction proposed by Monson et al. (2012). For comparison, it was also shown predictions by the light function proposed by Keller and Lerdau (1999) for tropical tree species in Panama. The parameters obtained for the best fit to the data in Figure 3 correspond to values reported in Guenther et al. (1999) assuming LAI equals to 0.5 (leaves near the top of the canopy). The fit indicates that the attempts to model isoprene emission using the Guenther et al. (1999) light algorithm were successful $\left(r^{2}=0.94\right)$. However, the $\alpha$ obtained from the best fit to the data was different among all leaf ages. The predictions by Keller and Lerdau (1999) light function, in general, showed good agreement with the data $\left(r^{2}=0.94\right)$, however this light function overestimated isoprene emission up to $500 \mu \mathrm{mol} \mathrm{m} \mathrm{m}^{-2} \mathrm{~s}^{-1}$ of PPFD for all leaf ages and overestimated isoprene emission at the highest PPFD level $\left(2000 \mu \mathrm{mol} \mathrm{m}^{-2} \mathrm{~s}^{-1}\right)$ for the senescent leaf (Figure 3).

Responses of isoprene emission to varying temperature for all leaf ages were different than photosynthesis responses (Figure $2 \mathrm{~d}-\mathrm{f}$ ). The temperature optimum of photosynthesis was about $37.5^{\circ} \mathrm{C}$ for senescent leaf, $-32.5^{\circ} \mathrm{C}$ for old mature leaf, and $-35^{\circ} \mathrm{C}$ for young mature leaf. In contrast, isoprene emission kept increasing exponentially with temperature, failing to exhibit an optimum even at temperatures well above photosynthesis temperature optimum.

The normalized temperature response of isoprene emission was modeled using the temperature algorithm of Guenther et al. (1999),

$$
\text { emission } \operatorname{rate}(T)=\frac{E_{o p t} \times C_{T 2} e^{C_{t 1^{X}}}}{C_{T_{2}}-C_{T_{1}}\left(1-e^{C_{t 1^{X}}}\right)}
$$


where

$$
X=\frac{\left(\frac{1}{T_{\text {opt }}}\right)-\left(\frac{1}{T_{L}}\right)}{R}
$$

and $T_{L}$ is leaf temperature $(K), R$ is the gas constant $\left(0.008314 \mathrm{~kJ} \mathrm{~K}^{-1} \mathrm{~mol}^{-1}\right), \mathrm{T}_{\text {opt }}$ is the temperature optimum $(\mathrm{K}), \mathrm{E}_{\text {opt }}$ is the emission rate $\left(\mathrm{nmol} \mathrm{m}^{-2} \mathrm{~s}^{-1}\right)$ at $\mathrm{T}_{\mathrm{opt}}$, and $\mathrm{C}_{\mathrm{T} 1}$ $\left(95 \mathrm{~kJ} \mathrm{~mol}^{-1}\right)$ and $\mathrm{C}_{\mathrm{T} 2}\left(230 \mathrm{~kJ} \mathrm{~mol}^{-1}\right)$ are empirical coefficients representing the energies of activation and deactivation, respectively. As data did not exhibit temperature optimum, this parameter was fixed at $47^{\circ} \mathrm{C}(320 \mathrm{~K})$. Again, prediction of the modified algorithm suggested by Keller and Lerdau (1999) is shown for comparison (Figure 6).

Senescent leaf showed the highest normalized $\mathrm{E}_{\text {opt }}$, hence this value was used to model the normalized isoprene emission for all leaf ages. Guenther et al. (1999) model showed a good fit to normalized data up $-40^{\circ} \mathrm{C}$, after that modeled isoprene emission differed among all leaf ages Keller and Lerdau (1999) model overestimated the isoprene emission at all leaf temperatures.
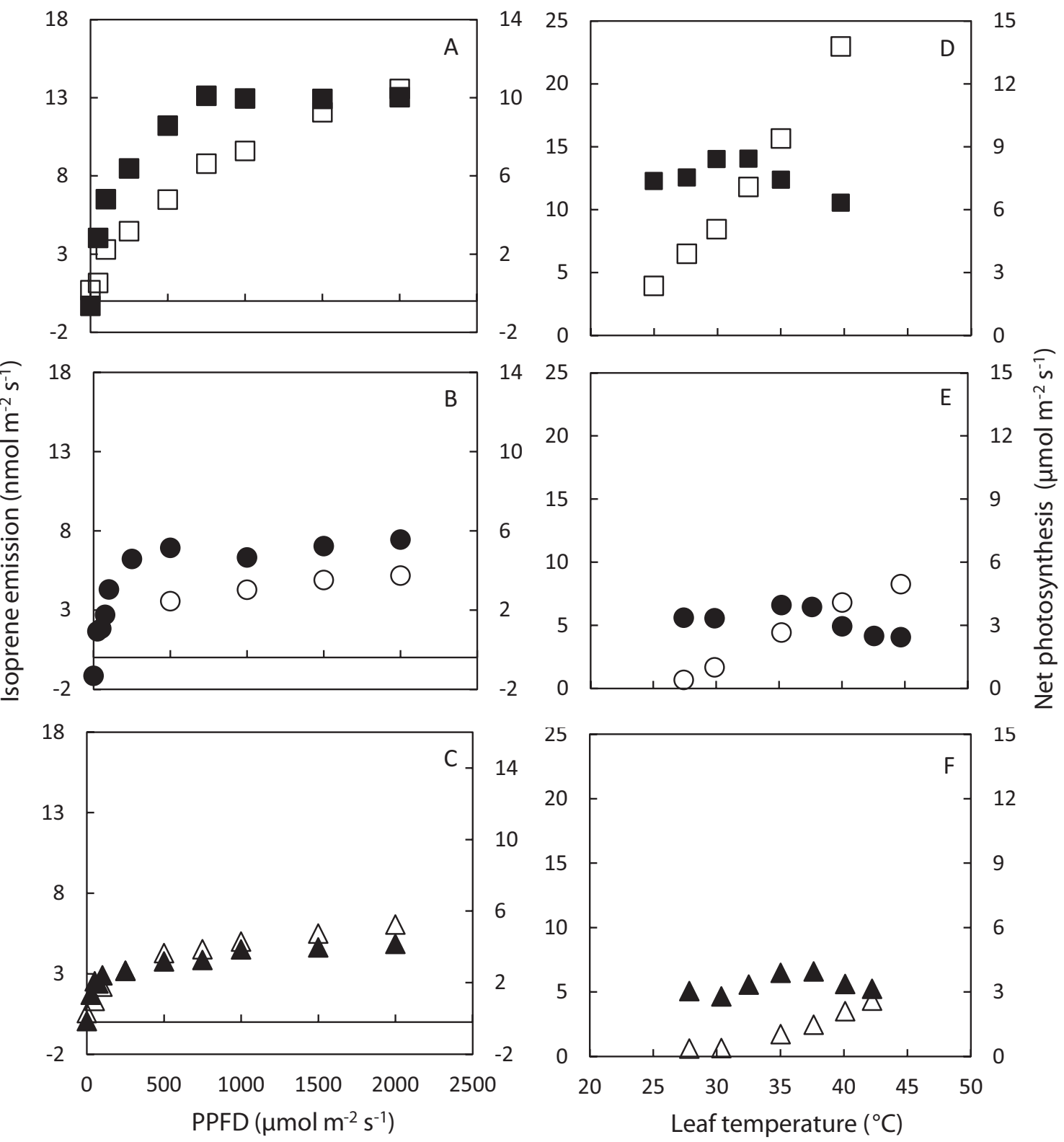

Figure 2 - Response of isoprene emission (open symbol) and net photosynthesis (dark symbol) from different leaf developmental stages of E. coriacea to variations in ligh availability and leaf temperature. Senescent leaf $(\mathbf{\Delta})$; old mature leaf $(\bullet)$; young mature leaf $(\mathbf{\bullet})$. 

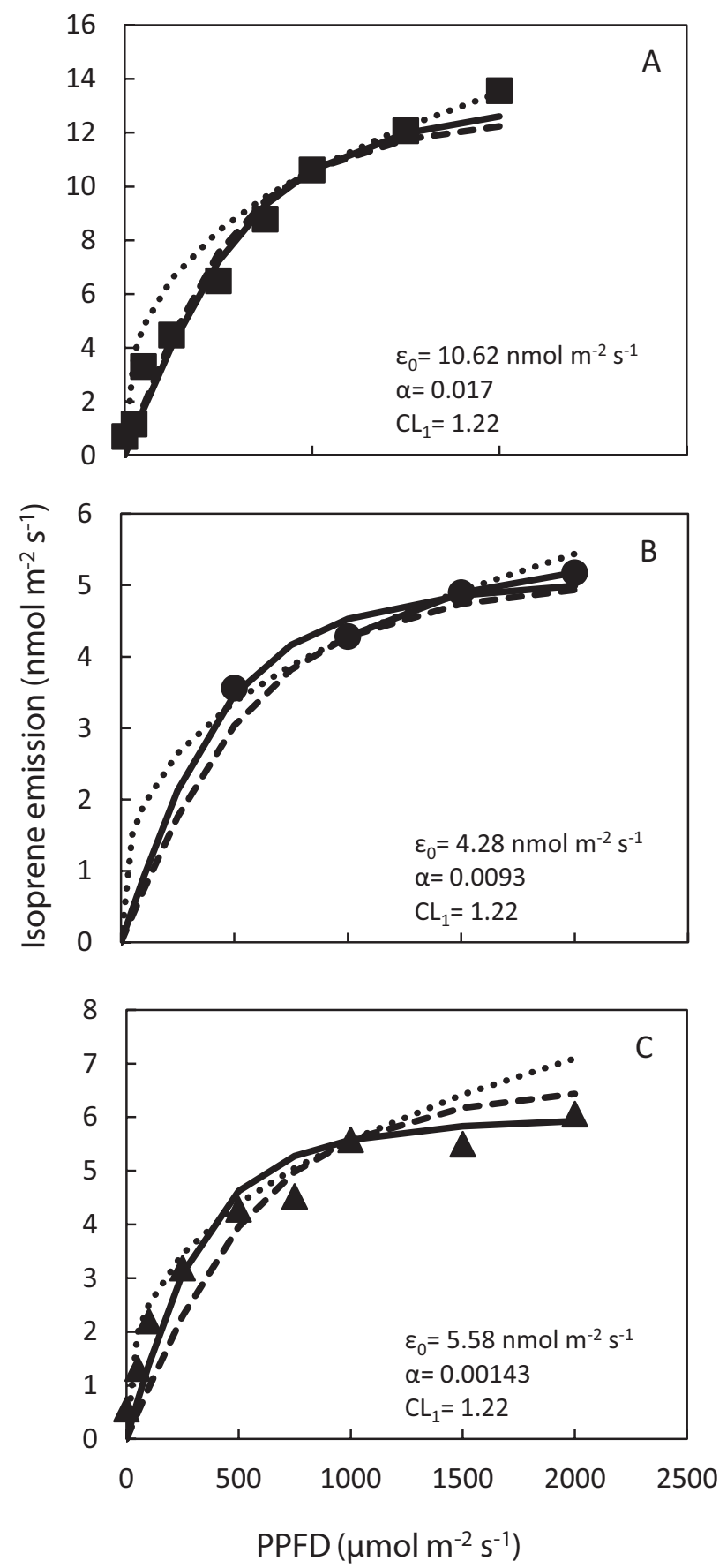

Figure 3 - Response of isoprene emission from different leaf developmental stages of E. coriacea to variations in PPFD. Parameters shown on each figure are based on non-linear least-square fits to the data (solid line) to Eq. (2). Model predictions are based on parameters $(\alpha=0.00142$ and $C L 1=1.22)$ suggested by Guenther et al. (1999) (dashed line); and based on the light function proposed by Keller and Lerdau (1999) (dotted line). Young mature leaf $(A)$; old mature leaf $(B)$; senescent leaf $(C)$.

\section{DISCUSSION}

\section{Isoprene emission capacity $\left(E_{s}\right)$ for different developmental stages}

Capacity of isoprene emission varied among different leaf ages, and the young mature leaf demonstrated the highest values of $E_{s}$. Our results are consistent with results for canopy tropical tree species Hymenaea courbaril in southwestern Amazon (Kuhn et al. 2004b), and indicate that inherent capacity of plant to synthesize isoprene changes during leaf development. This is because leaf physiological activity varies in dependence on leaf ontogenetic stage, increasing rapidly in developing leaves and decreasing in senescing leaves undergoing programmed cell death (e.g., Grassi et al. 2005; Niinemets et al. 2004).

It was observed that new leaves were beginning to flush even when older leaves were in the senescent stage, so that young mature leaves occurred mainly in the extreme top layer of crown and were exposed to very high levels of irradiance. The older non-senescent foliage gradually becomes shaded due to new foliage formation and expansion (Niinemets et al. 2006). In Quercus ilex, it has been demonstrated that, due to shading effects, 1-year-old leaves intercept 30\% less light than the current-year leaves, and that leaves over 3-years-old of age intercept $80 \%$ less light than they intercepted during their formation (Niinemets et al. 2006). Thus, the observed reduction in isoprene emission with increasing leaf age is accompanied by a reduction in intercepted radiation, and it is difficult to separate direct effects of leaf age and effects of radiation changes. Because high light availability in the extreme top layer is accompanied by high temperatures, it is also possible to suggest a role for varying temperature.

Nevertheless, besides the changes in physiological activity due to enhanced shading, there is also evidence of lower photosynthetic activity of older foliage at any given light availability (Niinemets et al. 2006); and overall decline in leaf physiological activity is also associated with strong reductions in foliage isoprene emission rates (Lehning et al. 2001; Mayrhofer et al. 2005; Sun et al. 2009). Therefore, although the young mature leaves occur on the extreme top layer, which can shade older leaves, results showed lower values for photosynthesis and isoprene emission of older leaves at all light availability applied, suggesting that $E_{s}$ resulted from reduced foliage physiological activity in dependence on leaf ontogenetic stage.

$E_{s}$ of young mature leaf $\left(8.45 \mathrm{nmol} \mathrm{m}^{-2} \mathrm{~s}^{-1}\right.$ - from temperature response curve; $9.6 \mathrm{nmol} \mathrm{m} \mathrm{m}^{-2} \mathrm{~s}^{-1}$ - from light response curve) were on the low end of the range of $E_{s}$ values reported for upper canopy tropical mature leaves from Panama, which demonstrated $E_{s}$ ranging from 9 to $43 \mathrm{nmol} \mathrm{m}^{-2} \mathrm{~s}^{-1}$ for all species screened by Keller and Lerdau 


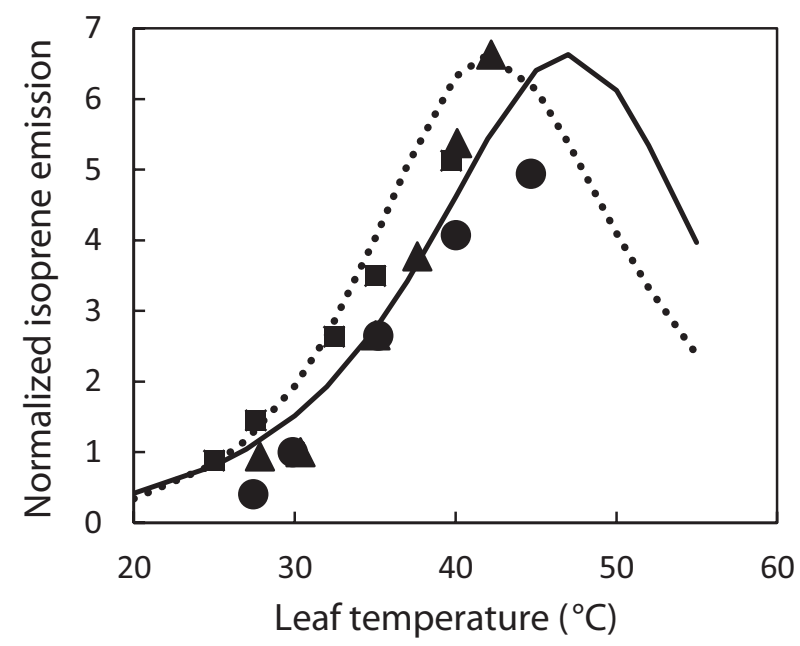

Figure 4 - Response of normalized isoprene emission (emission at $30{ }^{\circ} \mathrm{C}$ set equal to 1.0) from different leaf developmental stages of $\mathrm{E}$. coriacea to variations in leaf temperature. Model predictions are based on parameters suggested by Guenther et al. (1999) (solid line); and based on the algorithm modified by Keller and Lerdau (1999) (dotted line). Senescent leaf ( $\mathbf{\Delta})$; old mature leaf $(\bullet)$; young mature leaf $(\mathbf{\bullet})$.

(1999), and from 4 to $55 \mathrm{nmol} \mathrm{m}^{-2} \mathrm{~s}^{-1}$ for all species screened by Lerdau and Throop (1999). Additionally, Harley et al. (2004) showed results of $E_{s}$ of mature leaf of Mangifera indica equals to $66.5 \mu \mathrm{g} \mathrm{C} \mathrm{m}^{-2} \mathrm{~s}^{-1}$, and Kuhn et al. (2004b) showed results of $E_{s}$ of young mature leaves of Hymenaea courbaril equals to $111.5 \mu \mathrm{g} \mathrm{C} \mathrm{m} \mathrm{m}^{-2} \mathrm{~s}^{-1}$ in the southwestern Amazon, which exhibited higher values of $E_{s}$ than those presented for young mature leaf in this study $\left(14.56 \mu \mathrm{g} \mathrm{C} \mathrm{m} \mathrm{m}^{-2} \mathrm{~s}^{-1}\right.$ - from

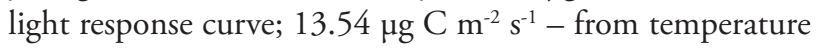
response curve).

Therefore, isoprene emission capacity does not vary only due to leaf development, but also enzyme activity to produce isoprene vary widely within and among species (Harley et al.1999; Kesselmeier and Staudt 1999), and vary due to light conditions and temperatures experienced by leaves in the days preceding the measurements (Sharkey et al. 1999; Pétron et al. 2001; Kuhn et al. 2004a).

\section{Light and temperature responses}

The response of isoprene emission and photosynthesis to varying light in this study approximated a rectangular hyperbola; this confirmed the light dependence of isoprene production and emission, which was also verified for other studies with tropical species (e.g. Keller and Lerdau 1999; Lerdau and Throop 1999; Harley et al. 2004; Kuhn et al. 2004a).

Our results showed light saturation for photosynthesis (at $1000 \mu \mathrm{mol} \mathrm{m}^{-2} \mathrm{~s}^{-1}$ of PPFD), but did not show light saturation for isoprene emission up to $2000 \mu \mathrm{mol} \mathrm{m}^{-2} \mathrm{~s}^{-1}$ (PPFD). This observation is supported by data of Keller and Lerdau (1999), and Lerdau and Throop (1999) who failed to observe light saturation in some tropical species up to $2000 \mu \mathrm{mol} \mathrm{m} \mathrm{m}^{-2} \mathrm{~s}^{-1}$ (PPFD). However, Harley et al. (2004) showed isoprene light saturation for $M$. indica at $1500 \mu \mathrm{mol} \mathrm{m} \mathrm{m}^{-2} \mathrm{~s}^{-1}$ (PPD), and Kuhn et al. (2004b) revealed isoprene light saturation below $1000 \mu \mathrm{mol} \mathrm{m} \mathrm{m}^{-2} \mathrm{~s}^{-1}$ (PPFD) for H. courbaril.

Therefore, it appears that light saturation for isoprene emission can vary between tropical species, even for species adapted to the same light environment. However, the reason(s) why photosynthesis saturates at lower light levels than isoprene emission is currently not fully understood. Grote and Niinemets (2008) suggest several possible reasons why isoprene emission might saturate at higher irradiance than photosynthesis, one of which is that at high light photosynthesis may not be able to utilize all the ATP or NADPH generated by electron transport (due to Rubisco limitations) and that this excess remains available for isoprene production (Niinemets et al., 1999).

The light algorithm of Guenther et al. (1999) showed a good fit to isoprene emission data, however the $\alpha$ values were different among all leaf ages. Monson et al. (2012) demonstrated that $\alpha$ depends on $E_{s}$ and this dependence become problematic when the isoprene emission rate vs. PPFD dependence is used to derive $\alpha$, especially in comparative studies when leaves or species that show different $E_{s}$ are compared. In those cases, the derived value of $\alpha$ will not just reflect inherent biochemical and photochemical constraints on $\mathrm{d}($ emission rate $) \mathrm{d}(\mathrm{PPFD})$, but also will include an influential component due to $\mathrm{d}($ emission rate $) \mathrm{d}\left(E_{s}\right)$. Therefore, as our data showed differences among $E_{s}$ of all leaf ages, changes in the modeled $\alpha$ could be influenced by changes in the $E_{s}$.

Isoprene data, Guenther et al. (1999) algorithm and Keller and Lerdau (1999) light function predictions agree closely at $1000 \mu \mathrm{mol} \mathrm{m} \mathrm{m}^{-2} \mathrm{~s}^{-1}$ (PPFD), however the Keller and Lerdau (1999) predictions do not capture well the isoprene emission up to $500 \mu \mathrm{mol} \mathrm{m} \mathrm{m}^{-2} \mathrm{~s}^{-1}$ (PPFD) and overestimated isoprene emission at the highest level of PPFD especially for senescent leaf. So, although Keller and Lerdau (1999) showed that this light function for isoprene emission is adequate to upper canopy tropical species, our results suggested that changes in isoprene emission due to changes in leaf developmental stages could not be captured by this light function. Thus, more studies are needed to elucidate which changes should be done in the models to capture leaf phenology effects on isoprene emissions.

Besides the differences of $E_{s}$ among all leaf ages, isoprene emission vs. PPFD showed differences among all three leaf developmental stages investigated. This indicates that the light saturation for isoprene emission could be different among leaf ages, demonstrating that biological changes due 
to aging can influence also on light response curve pattern of isoprene emission. These results disagree with previous results by Kuhn et al. (2004b) for $H$. courbaril, which state that only the inherent capacity of the plant to synthesize isoprene changes during leaf development, but not the instantaneous dependence on driving environmental factors.

It has been demonstrated that the shape of the isoprene temperature response, including the temperature optimum, depends on the rate of temperature increase (Singsaas and Sharkey 2000; Rasulov et al. 2010). However, the shape of the isoprene temperature response of this study agrees with data of Keller and Lerdau (1999) and Lerdau and Throop (1999), which showed that isoprene emission did not decrease until $-40{ }^{\circ} \mathrm{C}$ for different tropical species.

It was impossible to determine a distinct temperature optimum from our data, but on basis of data from old mature leaf it seems that the temperature optimum of isoprene emission of E. coriacea is above $45^{\circ} \mathrm{C}$, which is at least $10{ }^{\circ} \mathrm{C}$ higher than the temperature optimum for photosynthesis. These results differ from those presented by others studies with tropical species that suggested isoprene temperature optimum at about $40{ }^{\circ} \mathrm{C}$ (Lerdau and Keller 1997; Harley et al. 2004). This could mean that temperature optimum for isoprene emission of tropical species may vary considerably, so further field studies with different tropical canopy species are required to identify isoprene temperature optimum.

If the temperature optimum for isoprene emission is higher than $45^{\circ} \mathrm{C}$ for $E$. coriacea, this may confer greater thermal protection, consistent with a role for isoprene in enhanced thermotolerance (Singsaas et al. 1997). Given that higher temperatures are expected in the coming decades under global warming, it is possible that species with high isoprene emissions and with high temperature optimum may be favored. However, more studies are required to support this discussion, since it was demonstrated that temperature optimum of isoprene emission is influenced by the rate of temperature rising and by the substrate availability (Rasulov et al.2010).

The temperature algorithm of Guenther et al. (1999) did not show a good fit to normalized data at temperatures above $-40^{\circ} \mathrm{C}$. Additionally, the algorithm modified by Keller and Lerdau (1999) overestimated the isoprene emission at all leaf temperatures. This is because our data did not show isoprene temperature optimum for any leaf developmental stages. Therefore, more studies will be necessary to identify the temperature optimum for different leaf developmental stages of this species and for others, since this could help to better understand the potential of Guenther $e$ t al. (1999) to model isoprene emission vs. temperature for tropical species.

\section{CONCLUSIONS}

Leaf ageing caused a reduction of both isoprene emission capacity and photosynthetic rates, which was attributed to reduction in metabolic activity. Although the data fit on the basis of the light algorithm (Guenther et al., 1999) was satisfactory, the fit parameter $\alpha$ was different among all three leaf ages, likely due to differences in $E_{s}$. Moreover, because isoprene emissions from all leaves studied continued to increase with increasing leaf temperature, no optimum temperature was observable, but instead showed isoprene emissions continuing to increase up to $45^{\circ} \mathrm{C}$ which is significantly higher than previously reported for tropical tree species. Thus, the temperature algorithm of Guenther et al. (1999) did not fit to normalized data well at temperatures above $-40^{\circ} \mathrm{C}$ for any leaf age. Therefore, in order to improve models that predict isoprene emission from tropical forest ecosystems, more experimental information is needed on how species-specific isoprene emission capacity changes during leaf developmental stages, and to identify the temperature optimum of isoprene emissions.

\section{ACKNOWLEDGMENTS}

This research was supported by LBA, University of Arizona and National Center for Atmospheric Research (NCAR). Logistic support from LBA support staff is gratefully acknowledged, as is assistance from staff of NCAR and staff of Plant Physiology Laboratory of the INPA. JFC Gonçalves acknowledges a fellowship granted by the National Council for Scientific and Technological Development (CNPq, Brazil). Authors acknowledges Dr. David Adams for English corrections.

\section{REFERENCES}

Andreae, M.O.; Artaxo, P.; Brandão, C.; Carswell, F.E.; Ciccioli, P.; da Costa, A.L. et al. 2002. Biogeochemical cycling of carbon, water, energy,trace gases and aerosols in Amazonia: The LBAEUSTACH experiments. Journal of Geophysical Research, 107: 8066.

Araújo, A.C.; Nobre, A.D.; Kruijt, B.; Elbers, J.A.; Dallarosa, R.; Stefani, P. et al. 2002. Comparative measurements of carbon dioxide fluxes from two nearby towers in a central Amazonian rainforest: The Manaus LBA site. Journal of Geophysical Research, 107: 1-8090.

Arneth, A.; Monson, R.K.; Schurgers, G.; Niinemets, Ü.; Palmer, P.I. 2008. Why are estimates of global isoprene emissions so similar (and why is this not so for monoterpenes)? Atmospheric Chemistry and Physics, 8: 4605-4620.

Ferraz, J.; Ohta, S.; Sales, S. 1998. Distribuição dos solos ao longo de dois transectos em floresta primária ao norte de Manaus. In: Higuchi, N., Campos, M.A.A., Sampaio, P.T.B., dos Santos, J. (Eds.), Análise estrutural da floresta primária da bacia do 
rio Cuieiras, ZF-2, Manaus-AM, Brasil. MCT-INPA/JICA, Manaus, p. 109-144.

Grassi, G.; Vicinelli, E.; Ponti, F.; Cantoni, L.; Magnani, F. 2005. Seasonal and interannual variability of photosynthetic capacity in relation to leaf nitrogen in a deciduous forest plantation in northern Italy. Tree Physiology, 25: 349-360.

Grote, R.; Niinemets, Ü. 2008. Modeling volatile isoprenoid emissions - a story with split ends. Plant Biology, 10: 8-28.

Guenther, A.; Zimmerman, P.R.; Harley, P.; Monson, R.; Fall, R. 1993. Isoprene and monoterpene emission rate variability: model evaluations and sensitivity analysis. Journal of Geophysical Research, 98: 12609-12617.

Guenther, A.; Baugh, B.; Brasseur, G.; Greenberg, J.; Harley, P.; Klinger, L. et al. 1999. Isoprene emission estimates and uncertainties for the Central African EXPRESSO study domain. Journal of Geophysical Research, 104: 30625-30639.

Guenther, A. 2002. The contribution of reactive carbon emissions from vegetation to the carbon balance of terrestrial ecosystems. Chemosphere, 49: 837-844.

Guenther, A.; Karl, T.; Harley, P.; Wiedinmyer, C.; Palmer, P.; Geron, C. 2006. Estimates of global terrestrial isoprene emissions using MEGAN (Model of Emissions of Gases and Aerosols from Nature). Atmospheric Chemistry and Physics, 6: 3181-3210.

Hanson, D. T.; Sharkey, T. D. 2001. Effect of growth conditions on isoprene emission and other thermotolerance-enhancing compounds, Plant, Cell and Environment, 24: 929-936.

Harley P.; Monson R. K.; Lerdau, M. T. 1999. Ecological and evolutionary aspects of isoprene emission from plants. Oecologia, 118: 109-123.

Harley, P.; Vasconcelos, P.; Vierling, L.; Pinheiros, C.; Greenberg, J.; Guenther, A.; et al. 2004. Variation in potential for isoprene emissions among Neotropical forest sites. Global Change Biology, 10: 630-650.

Jardine, K.; Monson, R.L.; Abrell, L.; Saleska, S.R.; Arneth, A.; Jardine, A. et al. 2011. Within-plant isoprene oxidation confirmed by direct emissions of oxidation products methyl vinyl ketone and methacrolein. Global Change Biology, 18: 973-984.

Keller, M.; Lerdau, M. 1999. Isoprene emission from tropical forest canopy leaves. Global Biogeochemical Cycles, 13: 19-29.

Kesselmeier, J.; Staudt, M. 1999. Biogenic volatile organic compounds (VOC): an overview on emission, physiology and ecology. Journal of Atmospheric Chemistry, 33: 23-88.

Kuhn, U.; Rottenberger, S.; Biesenthal, T.; Wolf, A.; Schebeske, G.; Ciccioli, P. et al. 2004a. Seasonal differences in isoprene and light-dependent monoterpene emission by Amazonian tree species. Global Change Biology, 10: 663-682.

Kuhn, U.; Rottenberger, T.; Biesenthal, T.; Wolf, A.; Schebeske, G.; Ciccioli, P.; Kesselmeier, J. 2004b. Strong correlation between isoprene emission and gross photosynthetic capacity during leaf phenology of the tropical tree species Hymenaea courbaril with fundamental changes in volatile organic compounds emission composition during early leaf development. Plant, Cell and Environment, 27: 1469-1485.
Lehning, A.; Zimmer, W.; Zimmer, I.; Schnitzler, J. P. 2001. Modeling of annual variations of oak (Quercus robur L.) isoprene synthase activity to predict isoprene emission rates. Journal Geophysical Research, 106: 3157-3166.

Lerdau M; Keller M. 1997. Controls on isoprene emission from trees in a subtropical dry forest. Plant, Cell and Environment, 20:569-578.

Lerdau, M. T.; Throop, H. L. 1999. Isoprene emission and photosynthesis in a tropical forest canopy: Implications for model development. Ecological Applications, 9: 1109-1117.

Litvak, M.E.; Loreto, F.; Harley, P.C.; Sharkey, T.D.; Monson, R.K. 1996. The response of isoprene emission rate and photosynthetic rate to photon flux and nitrogen supply in aspen and white oak trees. Plant, Cell and Environment, 19: 549-559.

Loreto, F.; Velikova, V. 2001. Isoprene produced by leaves protects the photosynthetic apparatus against ozone damage, quenches ozone products, and reduces lipid peroxidation of cellular membranes. Plant Physiology, 127: 1781-1787.

Luizão, R.C.C.; Luizão, F.J.; Paiva, R.Q.; Monteiro, T.F.; Sousa, L.S.; Kruijt, B. 2004.Variation of carbon and nitrogen cycling processes along a topographic gradient in a central Amazonian forest. Global Change Biology, 10: 592-600.

Mayrhofer, S.; Teuber, M.; Zimmer, I.; Louis, S.; Fischbach, R. J.; Schnitzler, J.P. 2005. Diurnal and seasonal variation of isoprene biosynthesis-related genes in grey poplar leaves. Plant Physiology, 139: 474-484.

Monson, R.K.; Grote, R.; Niinemets, U.; Schnitzler, J.P. 2012. Modeling the isoprene emission rate from leaves. New Phytologist, 195:541-559.

Niinemets, Ü.; Tenhunen, J. D.; Harley, P. C.; Steinbrecher, R. 1999. A model of isoprene emission based on energic requirements for isoprene synthesis and leaf photosynthetic properties for Liquidambar and Quercus. Plant, Cell and Environment, 22: 1319-1335.

Niinemets, Ü.; Kull, O.; Tenhunen, J. D. 2004. Within canopy variation in the rate of development of photosynthetic capacity is proportional to integrated quantum flux density in temperate deciduous trees. Plant, Cell and Environment, 27: 293-313.

Niinemets, Ü.; Cescatti, A.; Rodeghiero, M.; Tosens, T. 2006. Complex adjustments of photosynthetic capacity and internal mesophyll conductance to current and previous light availabilities and leaf age in Mediterranean evergreen species Quercus ilex. Plant, Cell and Environment, 29: 1159-1178.

Niinemets, Ü.; Arneth, A.; Kuhn, U.; Monson, R.K.; Peñuelas, J.; Staudt, M. 2010. The emission factor of volatile isoprenoids: stress, acclimation, and developmental responses. Biogeoscience, 7: 2203-2223

Oliveira, A.N.; Amaral, I.L. 2005. Aspectos florísticos, fitossociológicos e ecológicos de um sub-bosque de terra firme na Amazônia Central, Amazonas, Brasil. Acta Amazonica, 35:1-16.

Oliveira, A.N.; Amaral, I.L.; Ramos, M.B.P.; Nobre, A.D.; Couto, L.B.; Sahdo, R.M. 2008. Composição e diversidade florísticoestrutural de um hectare de floresta densa de terra firme na 
Amazônia Central, Amazonas, Brasil. Acta Amazonica, 38: 627-642.

Pacifico, F; Harrison, S. P.; Jones, C. D.; Sitch, S. 2009. Isoprene emissions and climate. Atmospheric Environment, 43: 6121-6135.

Peñuelas, J.; Llusià, J.; Asensio, D.; Munné-Bosch, S. 2005. Linking isoprene with plant thermotolerance, antioxidants, and monoterpene emissions. Plant, Cell and Environment, 28: 278-286.

Pétron, G.; Harley, P.; Greenberg, J.; Guenther, A. 2001. Seasonal temperature variations influence isoprene emission. Geophysical Research Letters, 28: 1707-1710.

Rasulov, B.; Hüve, K.; Bichele, I.; Laisk, A.; Niinemets, U. 2010. Temperature response of isoprene emission in vivo reflects a combined effect of substrate limitations and isoprene synthase activity: a kinetic analysis. Plant Physiology, 154:1558-1570.

Schnitzler, J.P.; Lehning, A., Steinbrecher, R. 1997. Seasonal pattern of isoprene synthase activity in Quercus robur leaves and its significance for modeling isoprene emission rates. Botanical Acta, 11: 240-243.
Sharkey, T. D.; Singsaas, E. L. 1995. Why plants emit isoprene. Nature, 374: 769.

Sharkey, T. D.; Singsaas, E.L.; Lerdau, M.T., Geron, C.D. 1999. Weather effects on isoprene emission capacity and applications in emissions algorithms. Ecological Applications, 9: 1132-1137.

Singsaas, E. L.; Lerdau, M.; Winter, K.; Sharkey, T.D. 1997. Isoprene increases thermotolerance of isoprene emitting species. Plant Physiology, 115: 1413-1420.

Singsaas E. L.; Sharkey, T. D. 2000. The effects of high temperature on isoprene synthesis in oak leaves. Plant, Cell and Environment, 23: 751-757.

Sun, Z.; Niinemets, Ü.; Copolovici, L. 2009. Foliar isoprene emission during autumn senescence in aspen (Populus tremula). Geochimica et Cosmochimica Acta, 73: A1295.

Velikova, V.; Loreto, F. 2005. On the relationship between isoprene emission and thermotolerance in Phragmites australis leaves exposed to high temperatures and during the recovery from heat stress. Plant, Cell and Environment, 28: 318-327.

Recebido em 24/11/2012

Aceito em 21/03/2013 